Escuela y comunidad. La experiencia colombiana con los Proyectos de Servicio Social Estudiantil

\title{
School and community. The Colombian experience with Student Social Service Projects
}

\author{
W. Eduardo Ortega Torres. \\ Universidad Pablo de Olavide. \\ eduardoor803@gmail.com \\ M. Alejandra Vahos Anaya. \\ Universidad Pablo de Olavide. \\ mvanaya18@gmail.com \\ José Antonio Sánchez Medina. \\ Universidad Pablo de Olavide. \\ jasanmed@upo.es
}

\section{RESUMEN.}

Uno de los grandes problemas a los se que enfrenta actualmente la escuela, es que se generan conocimientos y procesos de aprendizaje encapsulados y desarticulados de las características del contexto que definen a sus estudiantes. Frente a este panorama, se plantea que el aprendizaje por servicio puede erigirse como una alternativa que logra articular los saberes de la escuela con la comunidad en miras de generar procesos de aprendizaje auténtico. A partir de estas premisas, este artículo presenta un estudio práctico sobre los Proyectos de Servicio Social Estudiantil (PSSE), como alternativa para superar la visión dualista escuela-comunidad. Los PSSE son un requisito estatal que todo estudiante de educación pública o privada de Colombia debe cumplir en los grados superiores y que, desde la teoría, se reconoce como un escenario de articulación entre la escuela, la comunidad y el individuo. Sin embargo, los hallazgos evidencian una serie de dificultades que han limitado su alcance formativo y dejan entrever un sistema educativo nacional históricamente fragmentado y lleno de carencias, desde el que la escuela necesita ser repensada y resignificada para fortalecer los procesos de aprendizaje y formación de los estudiantes.

\section{PALABRAS CLAVES.}

Escuela-comunidad, aprendizaje por servicio, aprendizaje auténtico, proyectos de servicio social estudiantil.

\section{ABSTRACT.}

One of the most difficult problems that the school is currently facing is that it generates encapsulated knowledge and learning processes that are disarticulated from the characteristics of the context which defines students. Against this background, it is proposed that learning- service can become an alternative that manages to articulate the knowledge of

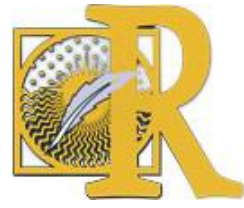

Fecha de recepción: 20-06-2020 Fecha de aceptación: 24-06-2020

Ortega-Torres, W., Vahos, A. \& Sánchez Medina, J. A. (2020). Escuela y comunidad. La experiencia colombiana con los Proyectos de Servicio Social Estudiantil 
the school with the community in order to generate authentic learning processes. Based on these premises, this article presents a practical study on Student Social Service Projects (SSSP), as an alternative to overcome the dualistic school-community vision. The SSSP is a state requirement that every student from public or private education in Colombia must meet in the upper grades and which, from the theory, is recognized as a scenario of articulation between the school, the community, and the individual. However, the findings show a series of difficulties that have limited its educational scope and reveal a historically fragmented and lacking national educational system, from which the school needs to be rethought and resignified to strengthen the learning and training processes of students.

\section{KEY WORDS.}

School-community, learning-service, real learning, Student Social Services Projects.

\section{Introduction.}

One of the most difficult problems that the educational system has traditionally faced is the generation of knowledge and learning processes encapsulated and disconnected from the community in which the students develop (Engestrom, 1991). According to Resnick (1987), the school seems to favor a type of learning of symbolic rules that do not maintain continuity between what is learned outside of school and what is learned in the educational system. This disconnection between the community and the educational system seems to be at the base of the difficulties in promoting an integral development of the student, strengthening their identity formation processes, and enhancing the ability to influence and transform their environment. This problem is exacerbated in marginal areas marked by violence, cycles of exclusion, stigmatization, and social stratification, which can replicate at scale in school, at the risk of turning it into an institution at the service of social inequality (Messiou, 2012).

A school isolated from the context that permeates its students runs the risk of promoting encapsulated knowledge that prioritizes formal teaching over other kind ok knowledge considered as non-formal, assuming that the former will be automatically transferred from the classroom to everyday life. But the case is that this decontextualized knowledge does not respond to the characteristics, interests, and cultural needs of the student, which consequently can lead the individual to look for "what he needs in everyday life" in other spaces different from the school. That is, when the school fails to be a bridge between learning and the everyday context, the development process tends to be fragmented and lose its meaning for the student, who ends up moving away from the classroom. This distance between the school and the everyday context has been illustrated in some research focused on the development of academic skills in everyday cultural contexts. For example, Nunes (1999); Abreu, Bishop \& Pompeu (1997) analyzed the differences in signs and reasoning between school mathematics and everyday mathematics in informal contexts.

Abajo \& Carrasco (2004) have studied How conditions of success and educational continuity are constructed when school connects with the daily students' needs and how this positively influences stigmatized groups. The aforementioned study focuses on gypsy students from different autonomous communities in Spain, including Castilla-León, Madrid, Aragón and Catalonia, who are traditionally in situations of socio-economic exclusion, which associated

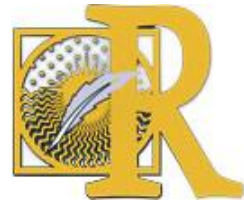


with high social and cultural rejection, and history of stigmatization and persecution, have consequently generated high rates of "general educational exclusion, absenteeism, failure and dropping out in gipsy boys and girls in the different educational stages" (Abajo \& Carrasco, 2004 , p. 98). This situation is reverted to a great extent when it is possible to approximate educational practices to the traditional daily practices of this group.

However, the debate continues on how to address these links between the school and the daily context of the students, because it is not a matter of prioritizing the decontextualized teaching-learning processes of the individual's environment, but neither is it that the entire educational process is focused on prioritizing the context and culture of the individual as the only way of learning-teaching. The latter is especially worrying when thinking about communities living in marginal areas since this radically applied strategy could limit the possibilities of social and cultural development, and therefore the promotion of equal opportunities offered by formalized knowledge to which is accessed from school. Consequently, power relations, social marginalization, and stigma of the population in a situation of social exclusion could be perpetuated (Goffman, 2006; Campo, 2003).

Against this background, there is recent literature that proposes an open dialogue between the knowledge of the community and the school to strengthen learning processes, generate opportunities for situated and significant development. One approach to overcome the dualistic school-context vision is the involvement and influence of parents in the educational processes of their children, whose participation, beyond the social-cultural group or socioeconomic situation, can positively influence the learning processes and consequently the academic performance and motivation of the students (Jeynes, 2007).

However, it is clear that opening the school to the community is not only about integrating parents but must also seek to include the support and mutual recognition of the school, families, and the community. For example, Santana, Feliciano \& Jiménez (2016) have analyzed the positive influence of family support and the integration of community knowledge on the academic-professional decisions of immigrant students, supporting their decisionmaking processes from an intercultural perspective, which contributes to a critical review of the student's life project. Flecha, García, Gómez \& Latorre, (2009) analyzed cases of educational success in contexts of students from families with a low socioeconomic status, immigrants, or cultural minorities. They identified the positive role of family participation and the community in training workshops, in academic-professional decision-making processes of students, in classrooms and learning spaces, and in shaping the curriculum exerted in the educational process and in the evaluation. In this line, Moliner (2008) also identified the positive impact of working together with community associations for educational inclusion, inquiring about the collaboration of these associations in networking, forums, seminars, working groups, in which professionals, parents and members of human rights associations are involved, to make community policies and practices a reality with an educational perspective.

As we have seen, there is empirical evidence that addresses the importance of connecting the school to the context and, above all, they stop to explore its impact and positive influence on the educational and training processes of the individual. These findings will be analyzed in light of the concepts of situated learning (Lave \& Wenger, 1991; and Rogoff, 1993, 1997,

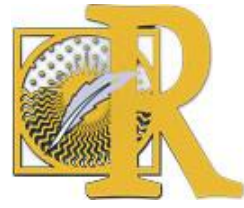

Fecha de recepción: 20-06-2020 Fecha de aceptación: 24-06-2020

Ortega-Torres, W., Vahos, A. \& Sánchez Medina, J. A. (2020). Escuela y comunidad. La experiencia colombiana con los Proyectos de Servicio Social Estudiantil 
2003); and real learning (Meijers, 2012). Framed under the premise that proposes learningservice (Pulg Rovira, Gijón, Martín \& Rubio, 2011) as an alternative that can achieve the articulation of school learning with the knowledge of the community. This alternative seeks to generate meaningful learning processes that also promote the identity development of students, development of educational scenarios, tools, and significate experiences. If the school can achieve this goal, it also can allow the students to appropriate the characteristics of their environment, transform difficulties into development opportunities, and put into practice the knowledge of the school for the construction of his life project.

Specifically, a practical approach to this commitment is presented in the Colombian educational system, who sensitive to these needs, proposes as a learning-service strategy the Student Social Service Projects (SSSP). A state requirement which every student of public or private education in Colombia must meet in the last two upper grades to be able to graduate and that, from theory, is recognized as a scenario of articulation between the school, the community, and the individual. The SSSP consist of the provision of social service to the community for a minimum of 80 hours that must be fulfilled extracurricular to the academic day, and its objective is to sensitize the student to the needs, interests, problems, and potential of the community; to contribute to the recognition, responsibility, and commitment to the environment; to promote educational actions aimed at building a spirit of service; to encourage the application of knowledge and skills learned in the classroom, and guide the student in their life project. Although various difficulties have been detected in practice that have limited its educational scope and hint at a historically fragmented and lacking national educational system, it is necessary to recognize its pedagogical possibilities as a case study to address the problem of a school it needs to be rethought and re-signified by its own educational actors. To investigate the SSSP as an alternative to the learning process related to the context, the research was articulated with the program "Mi comunidad es escuela"1 Program, a public investment initiative by the Mayor of Santiago de Cali, Colombia, to carry out actions aimed at improving the quality of the city's public education. Specifically, it was related to the axis of Student Social Service Projects, which reached the upper grades of 10 th and 11 th $^{2}$ of 45 Official Educational Institutions (IEO) and 59 educational sites ${ }^{3}$. This axis emphasized the need to build a pedagogical knowing that would make the intervention of the SSSP effective in the context and with them an action that would transform the school setting, based on the performance of the actors in the teaching-learning process.

In this sense, an approach to the concept of learning in practice and real learning will be made below; the research findings will be presented, which will allow recognizing the current status of the SSSP in the Colombian educational system, its legal framework, strengths, weaknesses and impact possibilities as a pedagogical and significant scenario. Finally, the introduction of key improvements as the first step towards educational change from the social service will be proposed.

\subsection{Situated learning.}

To start, it is pertinent to clarify that learning is understood as the process of acquiring knowledge and skills in a social environment; as an integral part of generative social practice in the world in which one lives (Lave \& Wenger, 1991); as a cultural process, connected with

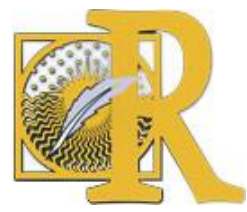

Fecha de recepción: 20-06-2020 Fecha de aceptación: 24-06-2020

Ortega-Torres, W., Vahos, A. \& Sánchez Medina, J. A. (2020). Escuela y comunidad. La experiencia colombiana con los Proyectos de Servicio Social Estudiantil 
life in all its senses (Vygostki, Cole \& Luria, 1989); as a social activity mediated by language and that takes place both with peers and with all the diversity of adult people with whom the students relate (Díez Palomar \& Flecha García, 2010); learning transforms what we are and what we can do, making it an experience of identity (Wenger, 2001); and ultimately, learning does not occur in a "social-institutional vacuum" but in contexts or activities that are sociocultural and institutionally defined (Scribner, 1980).

In accordance with the definition of the concept of learning and the problems identified in the formative processes, we propose to connect the training practices of the school with the knowledge of the context, through a perspective of learning in the practice that makes it possible to create spaces where students have the tools to build specific learning.

When considering learning as a situated process, where the individual, the interaction and the significant cultural activity in which he participates make up a constantly changing whole, it is "essential to consider the cognitive activities of individuals in the cultural context in which they have immersed his thought" (Rogoff, 1993, p.71). This means that development processes would not be reserved for the formal education field alone, but would also be present in the multiple daily activities that take place on a daily basis. A determining factor is that in these cultural practices we always share or recognize the other in a situated learning process, which introduces the concepts of guided participation by Barbara Rogoff (1993; 1997; 2003), understood as "the process and system of involvement of individuals with others, when they communicate and involve themselves in shared activities "(Rogoff et al., 1993, p. 6); and legitimate peripheral participation, developed by Lave \& Wenger (1991), which entail a process of involvement in a community or already established cultural practices, through participation that are initially peripheral, but legitimized by the community.

To achieve this articulation of educational processes with the knowledge of the community, it is therefore vital to think about learning in practice and to recognize the role of learning in the development of the individual himself. In this sense, learning-service is proposed as a possible way to overcome the dualistic vision that differentiates and distances the formal knowledge of the school from the cultural knowledge of the context.

According to the authors Pulg Rovira, Gijón, Martín \& Rubio (2011), the concept of learningservice integrates the possibilities of learning by doing and the premise of learning before, during and after the action, arguing that one must start from an x-ray of the social context and its protagonists, detecting the aspects in which work can be done to improve. This position distances itself from "assistant practice", proposing that the same context that impacts the process of identity construction of young people can also be linked to educative process so that it is the students themselves who generate actions to improve their social reality. In this way, work is carried out on the practical teaching of competences, responsible actions are promoted on the surrounding community and the responsible exercise of citizenship is facilitated.

Regardless of the specific content that addresses each of the experiences, service learning stands out for: learning from experience, cooperative learning, reflection on action, and guidance offered by adults. Therefore, in this conceptual proposal, educational institutions are the meeting point between the different agents who participate in this practice, that is, between students, family, community, and social entities. If the school succeeds in the first place,

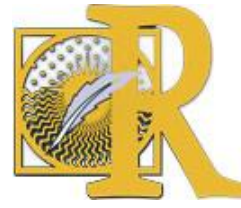

Fecha de recepción: 20-06-2020 Fecha de aceptación: 24-06-2020

Ortega-Torres, W., Vahos, A. \& Sánchez Medina, J. A. (2020). Escuela y comunidad. La experiencia colombiana con los Proyectos de Servicio Social Estudiantil al Journal of Educational Research and Innovation (IJERI), 14, 304-323 International JOurnal
ISSN: 2386-4303 DOI https://doi.org/10.46661/ijeri.4986 
characterizing and recognizing the cultural capital of the environment, and also integrating this knowledge in the areas of knowledge and academic work plans, by the time the student participates in alternative practices, such as learning-service, it will promote authentic cognitive and pedagogical processes. Which allows you to raise awareness, dialogue, and reflect with your environment from a more critical position and capable of generating transformations.

\section{Real learning.}

By linking school to context and bringing context to school in a situated learning process, truly meaningful cultural interactions and practices can be generated for the student development process. So this premise is articulated with the transversal concept of real learning presented by $\mathrm{F}$. Meijers (2002). For this author, real learning is a process where knowledge and emotions are gradually balanced, dialogically, to influence the development and construction of the individual's identity. From this perspective, Mejiers (2002) speaks of real learning when there is a situation that impacts the sensitivity of the being and this experience reaches an emotional charge that allows the appropriation of new concepts, knowledge, and skills. The incorporation of new learning is a continuous process that generates a change in the individual and in her life history. In other words, when an educational process is left alone in the knowledge and within the classroom as something that is delivered in a behavioral way, it fails to impact the depth of being and is soon forgotten. On the other hand, if emotions and feeling are linked in the teaching process, it is possible to reach the students' sensitivity so that they integrate what they have learned into their life experience.

Finally, we consider that real learning goes beyond cognitive recognition because it articulates the learning process with the emotional element that allows the individual to integrate knowledge into their own experience and life project. This learning implies a positioning, it is not only about knowledge in the abstract, but a commitment to that point of view that is going to be integrated into the learning process. For an educational development framed in the real learning proposal, it is necessary to recognize the demands and characteristics of the context that also define the student's life experience, and which must be linked, potentiated and transformed through the design of scenarios and practices that promote the real learning and manage to overcome educational prejudices that distance and limit.

\subsection{Research context.}

To understand why the SSSP stands as a case study in the face of the problem of a decontextualized school, it is necessary to first know the normative references that define them. Here we find as a legal framework Law 115 of February 8 of 1994, Decree 1860 of 1994 and Resolution 4210 of September 12, 1996, of the Ministry of National Education. In Colombia, Law 115 of February 8, 1994, establishes that all middle school students must realize obligatory social service during the last two grades of study, that is, in grades 10 and 11. According to Decree 1860 of 1994 of the Ministry of National Education, Chapter V Article 39 , this social service has the main purpose of integrating into the community to contribute to its social, cultural and economic improvement, collaborating with the development of values associated with solidarity and knowledge of the social environment by the student. And

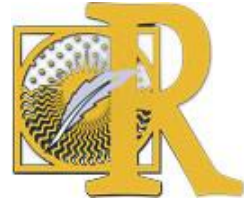

Fecha de recepción: 20-06-2020 Fecha de aceptación: 24-06-2020

Ortega-Torres, W., Vahos, A. \& Sánchez Medina, J. A. (2020). Escuela y comunidad. La experiencia colombiana con los Proyectos de Servicio Social Estudiantil 
according to resolution 4210 of 1996 , the student social service is outlined as a favorable scenario to make viable the function of the school as a social project and articulate the objectives of education with the realities of the students.

It could be said, that the SSSP are presented as a scenario through which all students must pass and that they can become an opportunity to propose alternatives to a disarticulated school with everyday life and encapsulated knowledge. Given its missionary meaning, it is necessary to clarify that when talking about social service, you should not limit yourself to referring to the 80 hours regulated by the legal basis that students must provide. The panorama must be broadened to find all the possibilities that this scenario gives, in relation to the teaching process, the student himself, the educational institution, the surrounding community, the region that surrounds it, and the country they inhabit. Along the same lines, talking about social service does not only refer to the institutional management, regulatory framework, legalization path, and effective compliance with this requirement to obtain a bachelor's degree. It also provokes to question what type of education is being promoted, what is being provided to the student on formation, how it contributes to teaching skills and development of life projects in students, what kind of citizen are train, how from education impacts and transforms society.

To begin, it is proposed to understand the SSSP as a process of continuous construction and collective participation, alluding to the constant passage of different students who are linked, citizens who are formed, alliances that are made, skills that are acquired, lessons learned, communities one can work with. Social service is not the same from one institution to another, nor is it lived the same from one student to another. Each educational center has institutional dynamics, regulations, a social context, teachers, and specific interests that vary the way they approach social service. In turn, each young person lives a different process in which their own identity formation, context, life project, among other elements, participate. In other words, SSSP should not be established as an immutable and static requirement; on the contrary, it must be recognized that they are made up of a series of different fluctuating elements. For example, student as a social subject in the process of formation and construction of identity; the contribution to the development of student competences, especially in relation to their life project; service with the community, based on a social impact that contributes to transformation; link with the context, that is, students become sensitized to a reality, influence and add experiences in these processes.

However, in practice, in the way in which this law is implemented in the concrete and particular scenarios of the city of Cali, the SSSP have encountered difficulties that have limited their scope, conditioned their possibilities of action, distorted their own sense and reduced its impact on the student-school-community relationship. By framing themselves in a decontextualized and encapsulated educational process, they end up being instrumentalized and reduced to an operational requirement that responds to a legal demand, not a space for reflection and development -as it had theoretically been projected. In addition, the directors see them as a matter of law to comply, teachers perceive them as an extra burden on their obligations, and for students, they are only a compulsory procedure to graduate, which results in educational actors often failing to visualize the possibilities offered by the SSSP to dialogue, interact and confront their environment.

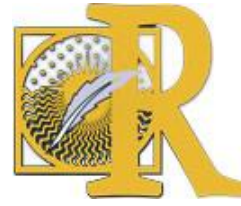

Fecha de recepción: 20-06-2020 Fecha de aceptación: 24-06-2020

Ortega-Torres, W., Vahos, A. \& Sánchez Medina, J. A. (2020). Escuela y comunidad. La experiencia colombiana con los Proyectos de Servicio Social Estudiantil International Journal of Educational Research and Innovation (IJERI), 14, 304-323 ISSN: 2386-4303 DOI https://doi.org/10.46661/ijeri.4986 
It is then a question of visualizing how a legal requirement which all educational institutions and students in the country must meet, can be strengthened and open a range of opportunities that favor their personal, educational, and social development. How can the established legal system be used to achieve an educational transformation and an effective articulation between the school and the context, between authentic learning processes and the breakdown of encapsulated knowledge? How to break obligatory paradigms, for the use of personal, institutional, and social initiative?

In the following chapter, those findings that are limiting the missionary sense with which the SSSP was conceived will be presented in a general way and will seek to shed light on the possibility of strengthening this space to project the full potential they offer by connecting the learning of the school with the knowledge of the community.

\section{Method.}

\section{Participants}

In 2018, the SSSP axis worked with 11 field professionals and managed to make 515 pedagogical visits to 45 institutions with 59 satellite campus, with the participation of 4,104 educational actors, including principals, coordinators, teacher leaders, students and community actors as parents. This sum is the total of the actors that were registered during all the activities implemented by 11 field professionals, but it is necessary to clarify that the same actor was able to participate in different activities. In addition, that some activities were carried out with all the courses between grades 9th, 10th and, 11th; while other activities focused on representative samples of the educational community, which, for example, varied between 15 and 20 participating students per activity.

As presented in Table 1, these visits were made between January to November 2018, and included a characterization phase ${ }^{4}$, characterization socialization, work tables for the construction of the action plan, socialization of the action plan, visits in situ for the formation of the articulators committee, life project workshops, pedagogical experience and accompaniment to practice. Dynamics in which it was highlighted the participation of teachers, including directors and coordinators, who led the processes of the SSSP, as well as the students who had to perform the social service and the educational institutions in which they framed the activities were significantly highlighted.

These participants include 83 teacher leaders, who assumed leadership of the SSSP management and mobilization processes from the institutional framework and are considered to be SSSP teacher leaders. Normally this work is assumed by teachers from different areas of knowledge who have leadership in the institutional management processes. Although in 16 institutions the participation of 3 principals and 22 coordinators was reported, in some cases due to the lack of an assigned teacher and in others due to the leadership of these administrative actors. The institutions had on average between 1 and 4 leading SSSP teachers, depending on their number of satellite campuses; but in 4 cases, the same teacher was reported for several sites. For example, the rector Nelly Guayupe of the Isaías Gamboa institution carried out SSSP leadership tasks at the Aguacatal and Inmaculada satellite campus.

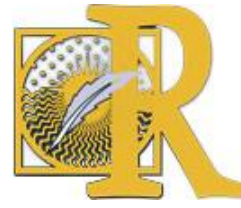

Fecha de recepción: 20-06-2020 Fecha de aceptación: 24-06-2020

Ortega-Torres, W., Vahos, A. \& Sánchez Medina, J. A. (2020). Escuela y comunidad. La experiencia colombiana con los Proyectos de Servicio Social Estudiantil

International Journal of Educational Research and Innovation (IJERI), 14, 304-323 ISSN: 2386-4303 DOI https://doi.org/10.46661/ijeri.4986 
Table 1. Quantitative registry of participants and visits.

\begin{tabular}{lrr}
\hline $\begin{array}{l}\text { Student Social Service Projects } \\
\text { "Mi comunidad es escuela" } \\
\text { January - November 2018 } \\
\text { Activities }\end{array}$ & Participants & Visits \\
\hline Characterization & 1298 & 115 \\
\hline Characterization socialization & 432 & 53 \\
\hline Work table 1 & 224 & 60 \\
\hline Work table 2 & 256 & 56 \\
\hline Work table 3 & 44 & 11 \\
\hline Accompaniment to practice & 573 & 52 \\
\hline Socialization of the action plan & 112 & 54 \\
& & \\
\hline Accompaniment activity 1 & 174 & 24 \\
\hline Accompaniment activity 2 & 933 & 47 \\
\hline Accompaniment activity 3 & 107 & 19 \\
\hline Articulators Committee & 65 & 7 \\
\hline Pedagogical experience & 742 & 47 \\
\hline Life project workshops & 77 & 18 \\
\hline Total & $\mathbf{4 1 0 4}$ & $\mathbf{5 1 5}$ \\
\hline
\end{tabular}

Source: Follow-up report on the Basic Skills Strengthening Project.

There was also the participation of 3,533 students between 13 and 18 years old, with a social diversity that fluctuated between low-income socioeconomic strata. Of this total, 1,215 students from the 9th, 10th, and 11th grades participated in the characterization workshops, and 2,318 were broken down into representative samples between 15 and 20 students from these same grades, who attended life project workshops, pedagogical outings and integrated the articulator's committee that worked on the collective development of the action plan.

The project reached up to 45 Official Educational Institutions and 59 satellite campus, with 515 visits between January and November 2018. Of the total of the institutions, 13 were located in rural areas and 32 in urban areas. Of the latter, 16 are located in areas considered difficult to access, regarding transportation and security. In general, these 45 institutions were located in areas of the Territories of Inclusion and Opportunities (TIO) strategy of the Mayor's Office of Santiago de Cali, which aimed to focus and strengthen development processes in the most vulnerable territories of the city.

\section{Data collection instruments.}

Two procedures were proposed to collect the data from the research, participant observation, and a documentary review. For the participant observation process, the workspaces with the 11 accompaniment professionals were vital, with weekly meetings to review the methodological guidelines of the intervention and follow up on the events, agreements, obstacles, and weaknesses found in the work with the institutions; meetings with the directors

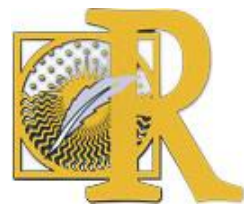

Fecha de recepción: 20-06-2020 Fecha de aceptación: 24-06-2020

Ortega-Torres, W., Vahos, A. \& Sánchez Medina, J. A. (2020). Escuela y comunidad. La experiencia colombiana con los Proyectos de Servicio Social Estudiantil 
of institutions that required special attention and actively leading some activities. On the other hand, the documentary review consisted of receiving, reading, analyzing and discussing all the documents that the professionals organized, wrote and designed about the intervention in the 45 institutions, including qualitative reports on activities carried out and quantitative matrices on the number of visits carried out, number of activities, number of participants and progress data.

\section{Procedures}

As can be seen in Table 2, at the methodological level, there were three phases of work, characterization, construction, and implementation of the action plan. The first phase focused on the characterization and recognition of the current state of the institutions, through the design and implementation of two instruments: a semi-structured interview with leading teachers and a workshop with 10th and 11th-grade students. The second phase of the work focused on the formation of the articulating committees and the collective construction of an action plan that, through different pedagogical strategies, responded to the particularities and needs of each institution in order to strengthen the SSSP. And the third phase of implementation focused on monitoring the progress of the action plan built with the articulation committees and management boards, in addition to workspaces with students such as life project workshops and pedagogical experience.

Table 2. Procedure and instruments for data collection.

\begin{tabular}{|c|c|c|c|}
\hline Phase & Activity & Institutions deliverables & SSSP deliverables \\
\hline 1.1 & Characterization & $\begin{array}{lll}\text { Characterization } & \text { report } & - \\
\text { Characterization } & \text { matrix } & - \\
\text { Executive report } & \end{array}$ & General report and executive report \\
\hline 2.1 & $\begin{array}{l}\text { Articulators } \\
\text { Committee }\end{array}$ & Information Sheet & \\
\hline 2.2 & Action plan design & $\begin{array}{l}\text { Action plan report - Action plan } \\
\text { matrix }\end{array}$ & General report \\
\hline 3.1 & $\begin{array}{l}\text { Articulators } \\
\text { Committee } \\
\text { Empowerment }\end{array}$ & $\begin{array}{l}\text { Articulators Committee } \\
\text { Empowerment report }\end{array}$ & General report \\
\hline 3.2 & $\begin{array}{l}\text { Management boards } \\
\text { conformation }\end{array}$ & $\begin{array}{l}\text { Progress report on } \\
\text { accompaniment at intersectoral } \\
\text { boards - Participatory evaluation } \\
\text { document }\end{array}$ & $\begin{array}{l}\text { Progress report on accompaniment at } \\
\text { intersectoral boards - Participatory } \\
\text { evaluation document }\end{array}$ \\
\hline 3.3 & $\begin{array}{l}\text { Life } \quad \text { project } \\
\text { workshops }\end{array}$ & Life project workshops report & General report \\
\hline 3.4 & $\begin{array}{l}\text { Pedagogical } \\
\text { experience }\end{array}$ & Pedagogical experience report & General report \\
\hline
\end{tabular}




\section{Results.}

During the research, different participatory instruments have implemented that bet on opening spaces to raise awareness and rethink the SSSP and education itself. To carry out this work, the educational actors were mobilized, and led to debate and questioning, to reflection on operational practices that have become naturalized. With the excuse of the SSSP, it was possible to unravel an educational background that has limited the possibilities of individual development.

\section{Characteristics.}

As a starting point, it was vital to understand that the practical center of the SSSP is determined by its implementation modality. The institutions have two modalities of implementation of the SSSP: internal and external. More than $80 \%$ of the 45 characterized institutions, prioritize the activities carried out within the educational establishment, with tasks such as teaching support, administrative support, embellishment of the institution, as may be observed in Graph 1. This percentage responds to different factors such as the absence of guidelines to manage agreements with external entities, lack of students' budget to supply transportation and food expenses, students who work against the clock to help their families, questions about the safety of students when leaving the educational facilities, and concerns regarding the institution's civil liability. The SSSP implementation modalities focus consistently on those carried out within the institution, so there is a general perception that SSSP can also function as an operational solution for the practical requirements of the institutions, responding to the own needs of the educational establishment, but leaving aside the community initiatives and the interests and needs of the students.

Graph 1. Implementation modalities of SSSP.

\section{Institutions}
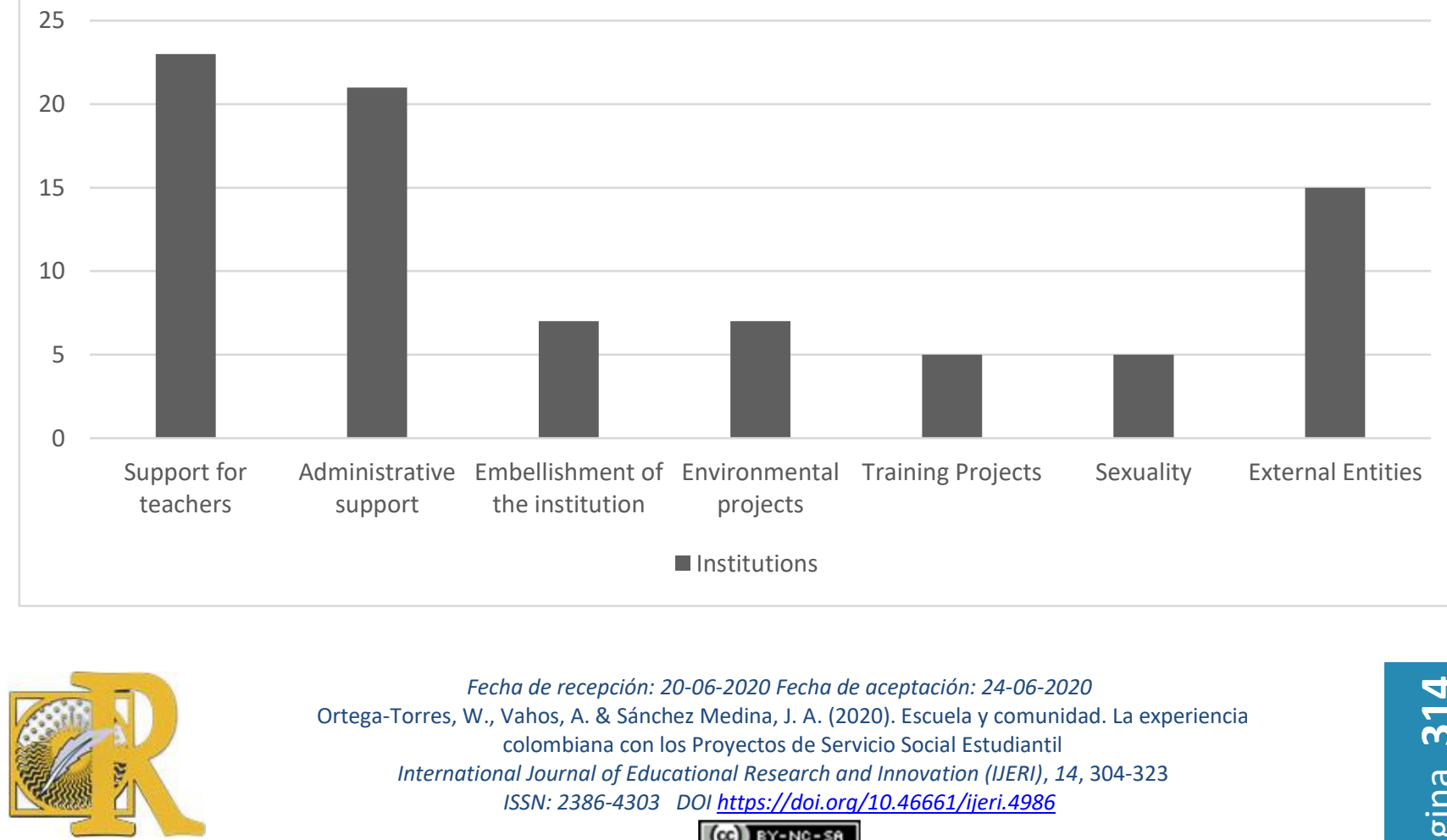

Fecha de recepción: 20-06-2020 Fecha de aceptación: 24-06-2020 


\section{Strengths.}

Initially, most of the strengths identified referred to the way in which SSSP implementation contributes to the construction of the person and not to the operational way in which it operates within the institutions. However, by delving into the recognition of strengths and achievements through the different phases of practical work, educational actors began to focus only on the operational and regulatory scopes that contributed to compliance with the legal framework of social service. In any case, although there is a holistic recognition of the learning possibilities offered by the SSSP, in practice the operational achievements are of primary interest.

These operational and regulatory achievements included, for example, the formal appointment of the leading teachers responsible for the SSSP and pacts in the work schedule; articulation with the institutional modality; incorporation into the Coexistence Manual. As well as recognition of possible public and private organizations, to create new alliances that expand training offer and generate new ties with the students' life projects; And initial training, before the 80 hours, in order to sensitize students to social service, and promote workdays with the students.

\section{Difficulties, needs and alarms.}

Despite the characteristics, strengths and achievements identified, together with a solid legal framework that ensures the implementation of the social service, the institutional perspective and the voices of educational actors repeatedly agreed on different difficulties faced by the SSSP. In other words, the law theoretically gives all the necessary instruments to achieve operational objectives, prioritizing compliance guidelines, organization, control, numerical results; but in practice, it falls short in the face of pedagogical possibilities and challenges. These weaknesses of an operational nature are perceived as incapacitating, demanding, and obligatory to be solved for the fulfillment of the law, that they even leave out of the debate the pedagogical sense of the SSSP. Among these findings we find:

- Weak institutional management processes that generate a disarticulation between the reality of their environment and their students.

- There is no response to the demands of the context or it is preferred to distance from the context due to the social problems that permeate it.

- Lack of formalization of agreements with other entities, which affects their management and continuity.

- The development of the educational center as a practical scenario for the development of basic competences, life skills, and authentic learning is not achieved.

- No new learning spaces are opened for students.

- Students or the community are not linked in participatory designs of learning processes.

- Lack of institutional clarity regarding legal issues of social service, both within the institution itself and in its communication processes towards students and the context.

- General perception that the institution does not give importance to the implementation of the SSSP. 
These limiting realities, added to other difficulties such as the vision of the students of the obligations to graduate, have not allowed the SSSP to explore all the potential they have to offer within the educational processes, and especially in the commitment to the articulation between school and context.

\section{Successful SSSP.}

After analyzing the strengths and weaknesses of the SSSP, it was necessary to recognize how these operational and pedagogical characteristics were translated into educational practice. Above all, how educational actors perceived these scenarios from the experience and within the framework of their requirements, and in their possibilities of transforming the students, their context, and the institution itself. Under this scenario, the category of successful SSSP was explored, understood as those social service scenarios that manage to effectively articulate operational issues that respond to the requirements of the law; and pedagogical issues that promote a contribution to the community and to the educational process of the students. In other words, those SSSP are clear about what is going to be done and what their meaning is. A successful social service is one that generates a comprehensive process that promotes authentic learning, strengthens the life project of the students, and manages to influence their identity formation while responding to the practical requirements necessary for proper compliance.

This approach to institutional reality will confirm the importance of responding to certain conditions necessary to ensure the success of the SSSP, where it is vital: 1. recognize and relate to the cultural context, while seeking a school-context articulation; 2. achieve articulation with the students' life project, because participation in a meaningful experience allows influencing and transforming their identity construction; and 3. have good institutional articulation. Although articulation with the context is necessary, it is not enough to generate a truly meaningful experience, there must be an articulation with the interests and life projects of the students in order to approach this comprehensive success dimension. In turn, institutional articulation is a no less important prerequisite, but easier to work as it is more easily adjusted to the operational dynamics naturalized in the institutions and is the most referenced by the different educational actors.

\section{Discussion and Conclusions.}

Why do we consider that the SSSP can become pedagogical and formative scenarios? Why do we believe that SSSP can generate significant mediated actions and effective appropriation processes? Why SSSP can strengthen critical thinking to influence ourselves and our environment? Because if we approach and work on the SSSP at the institutional management level, articulation with the context and strengthening of the individual's life project, all supported in an indisputable legal framework, we could propose a pedagogical, formative and social insertion scenario that opens up alternatives to a disarticulated school with daily life and encapsulated knowledge.

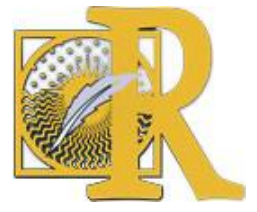

Fecha de recepción: 20-06-2020 Fecha de aceptación: 24-06-2020

Ortega-Torres, W., Vahos, A. \& Sánchez Medina, J. A. (2020). Escuela y comunidad. La experiencia colombiana con los Proyectos de Servicio Social Estudiantil

International Journal of Educational Research and Innovation (IJERI), 14, 304-323 ISSN: 2386-4303 DOI https://doi.org/10.46661/ijeri.4986 
Although the research perspective is clear, it is necessary to recognize a series of limitations of the methodology used and of the study itself, which, although they influenced the results, did not prevent the implementation of the intervention and helped to glimpse new possibilities to strengthen this type of initiatives. To start, this research was carried out within the framework of a government project that is restricted to the duration of the local government mandate and therefore is not considered as a continuous project or with temporary stability. The temporary and governmental restriction hindered a real impact on educational dynamics, did not ensure the incorporation and implementation of the findings in institutional guidelines and prevented continued funding to support the process. Being an external project, it was also possible to perceive a certain resistance on the part of the educational actors, because many were afraid that shortcomings could be found that would harm the institutional image and their own work. This resistance was found in several teachers, who participated in the construction of the instruments, but continually argued that they had other priorities that impeded their empowerment. Finally, arriving at the institution with various activities and intervention actors, could at times generate an overload of responsibilities and overtime for the different institutional actors. These were some of the identified limitations that affected the intervention, but which justly demonstrates the need to generate continuity in this type of initiatives to achieve an articulation with institutional logic, an appropriation of educational actors within their daily responsibilities, and a is committed to rethinking the meaning of education.

In short, it is time to stop and re-signify education and social service as a space for learningservice and real learning for the development of the individual, which generates practical actions that transform the school scene and impact the training process of educational actors. From these premises and the results found, the following are proposed as routes of action: strengthen teacher training and their sensitivity as a militant agent; articulation with the context through open schools with management bodies; the possibility of changing the way it is taught in the classroom from the curriculum; and create paths to reach students through authentic learning that impacts and transforms their identity formation process. Finally, the intervention work from which the investigation was framed was also proposed as the basis for the construction of a municipal resolution in Valle del Cauca that will manage to strengthen social service in the region and can be a bridge towards the construction of a public policy that can impact at a national level.

This means that a series of structural needs to be solved that go beyond the object of the research were recognized; but without renouncing the projection of restructuring the educational system and without pretending to have the absolute solution, the introduction of key improvements was proposed as the first step towards educational change from the social service. These possible lines of action require that school rethink education and specifically social service as a significant space.

The first line of action proposed was the need to work with teachers as essential agents, militants, and transformers of the educational process. Teachers have been permeated by an operational and fragmented educational reality, their formative practices have been limited by a feeling of lack, their critical sense has been bend by a system not disturbed by the characteristics of the context, their work is exhausted among the academic load overtime, evaluations and management processes to be able to subsist in an institution that conditions

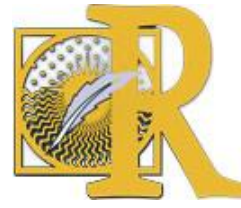

Fecha de recepción: 20-06-2020 Fecha de aceptación: 24-06-2020

Ortega-Torres, W., Vahos, A. \& Sánchez Medina, J. A. (2020). Escuela y comunidad. La experiencia colombiana con los Proyectos de Servicio Social Estudiantil International Journal of Educational Research and Innovation (IJERI), 14, 304-323 ISSN: 2386-4303 DOI https://doi.org/10.46661/ijeri.4986 
them. And it is precisely teachers, who have been losing their essence and mission, the main educational actors who could influence the process of identity construction and development of young people daily. For this reason, we must begin to work with them in the deconstruction of the learning and teaching process, in linking teaching practices with knowledge of the community, board the construction of identity and life projects of students. It is time for teachers to understand that their action is political, that they must be restless before a dominant system and that they have the ability to re-signify their work. If teachers identify with the community, recognize their problems and needs, articulate the context with a pedagogical sense, with an ethical sense of their practice, they could begin to improve their own teaching and the learning possibilities that they offer their students.

Once it is possible to bet on critical and sensitive work with teachers, it is proposed to continue articulating with the context through open schools with management bodies. If teachers are clear about the missionary meaning of educational practice and the SSSP, their participation, contribution, and position in these management bodies can be much more active and militant. When the teacher recognizes the meaning and the pedagogical possibilities that can be opened for their students, their action can be accompanied by this type of management and methodologies strategies at the institutional level, weaving collective networks that bring the school to the community and the community to the school. For 2019, as provide in the figure 2 , it was found that $60 \%$ of the characterized institutions had inter-institutional agreements with public, private, and/or community entities and $40 \%$ did not have any type of agreement with external entities. However, among the institutions with agreements, not all had it formalized in writing, in many institutions the alliances operated under verbal agreements. In the 27 institutions that reported inter-institutional agreements, 44 existing alliances were identified and about 39 agreements were obsolete. But, for example, if the creation of articulation committees and intersectorial boards are strengthened, it can create relevant processes that could be articulated, and contextualized to put the community in dialogue with the school.

Graph 2. Inter-institutional agreements.

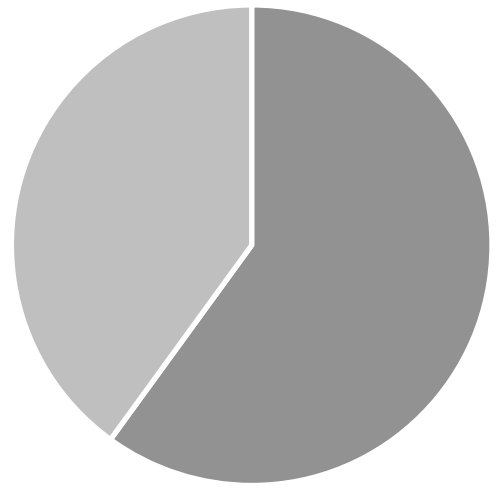


If it is possible to sensitize teachers and create institutional management bodies that link the school to the context, the next proposed line of action is to change the way it is taught in the classroom from the curriculum ${ }^{5}$. If the social service can be re-signified, educational guidelines like the curriculum, the Institutional Educational Proyect ${ }^{6}$, and the Institutional Improvement Plan $^{7}$ would begin to become obsolete in the face of specific realities that they do not recognize. It is not proposing to change the curriculum on paper so that later the pedagogical practices are changed. On the contrary, the pedagogical practices should first be changed from the heart, the life and the gaze of the teachers who are daily in the classroom so that the distancing of the curriculum from the specific needs to which it should be aimed is thus evidenced.

In effect, the change in the curriculum must be consistent with classroom teaching. However, in order to modify educational practices, the support of pedagogical discourse is required; and, in order to change the pedagogical discourse, learning in the classroom must be transformed and re-signified. Some possible changes in the curriculum matrix could be the proposal of the institutions to include a life project course that works in the interests, projections and identity development of students from an early age, and the possibility of recognizing the knowledge of the context and implementing the learning of the school from the lower grades, not only in the last grades of 10th and 11th. In other words, it could be suggested that this type of scenarios and methodologies can be implemented transversally from grade 6th, so that students, rather than complying with social service as a mandatory requirement, would be able to build a social service project that would go further than 80 hours and would be based on the interests and capacities of the students who have conceived them. Or one could even think about integration with vocational guidance processes aimed mainly at students who are close to accessing higher education ${ }^{8}$ and are faced with a range of possibilities and decisions that influence their future.

Changes in teaching practices, institutional management processes, and adjustments in the curriculum matrix lead to the most important line of action: the impact on the process of development and identity formation of the individual. Targeting change at the institutional level would help to work on change at the individual level, so students would also begin to care for their life projects, dreams, professional, and job prospects. This is one of the reasons why the intervention also aimed to identify possible scenarios suggested by students for the development of social work, understanding that the SSSP are spaces to help others, but they are also scenarios to meet, develop and strengthen their view of themselves and its context. As a result, in Graph 3, it can be seen that artistic projects were highlighted in 25 of the 45 institutions characterized. In 23 institutions there was a focus on sports activities and in 17 institutions the students proposed activities directly articulated with the strengthening of their life project, generating spaces for dialogue that allowed thinking and projecting possible routes of action.

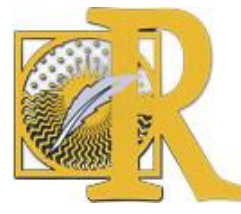

Fecha de recepción: 20-06-2020 Fecha de aceptación: 24-06-2020

Ortega-Torres, W., Vahos, A. \& Sánchez Medina, J. A. (2020). Escuela y comunidad. La experiencia colombiana con los Proyectos de Servicio Social Estudiantil

International Journal of Educational Research and Innovation (IJERI), 14, 304-323 ISSN: 2386-4303 DOI https://doi.org/10.46661/ijeri.4986 
Graph 3. SSSP suggested scenarios.

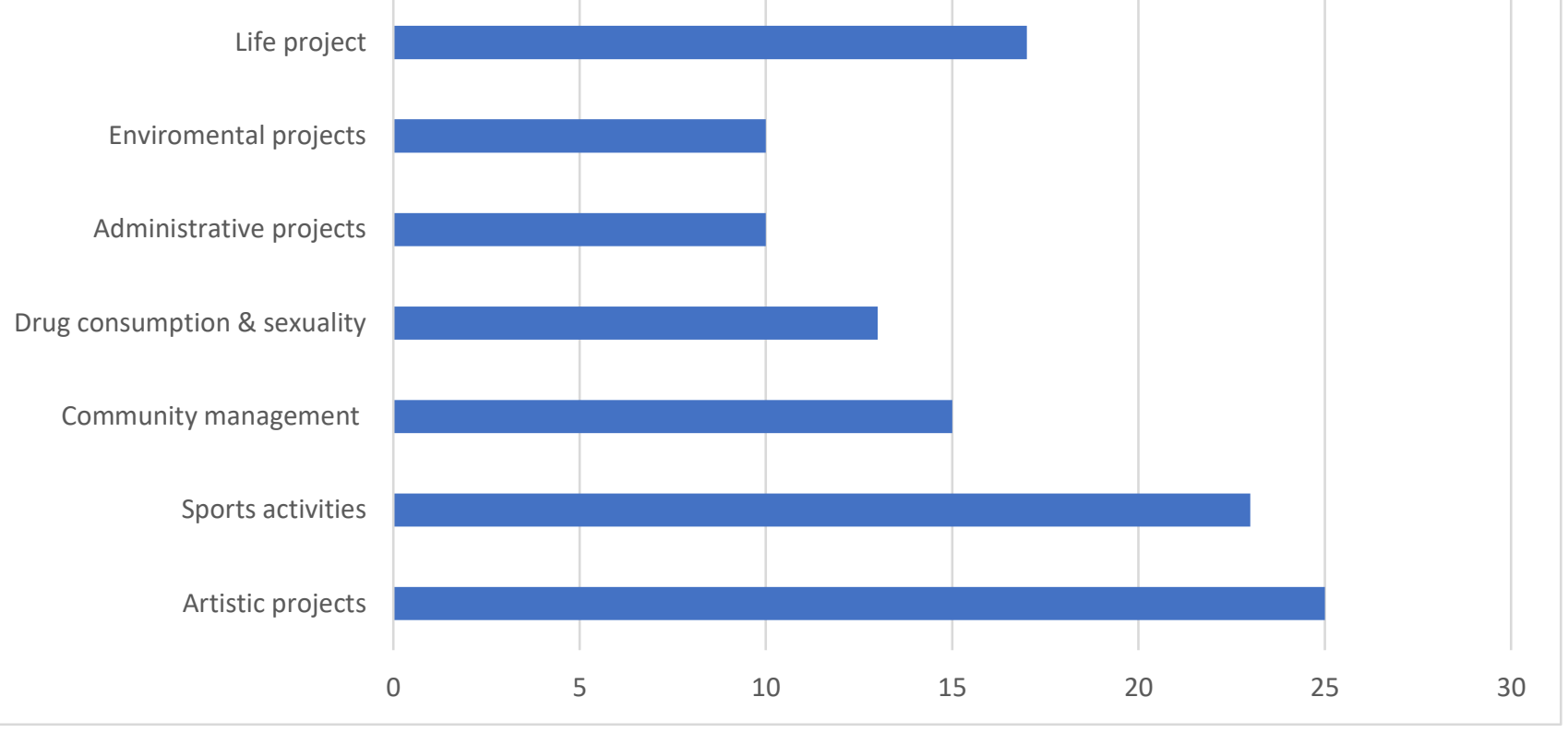

The proposed lines of action start from the macro to the micro, from the resignification of an educational system through teachers, institutional management, articulation with the context and curricular adjustments, in order to significantly influence the students. But also from the micro to the macro, given that if real learning scenarios are generated that affect the identity construction of the individual, one could begin to rethink the very meaning of the SSSP and its educational scope. In parallel, it was proposed to work with teachers, students, the community and the institution to achieve the resignification of the teaching exercise from the social service; which collaterally reflected flaws in the national educational system that, although they go beyond the purpose of this research, it was important to recognize in order to have clear arrival points.

Finally, this new scenario would give the opportunity to explore more strongly the educational possibilities that had previously been limited: creating a platform of mediation between the context and the school, between learning to do and thinking, between practical action and the pedagogical sense; between real learning and student development. From the theory, the SSSP as a learning-service strategy provides us with the possibility of generating specific aspects and real learning where there is a dialogue of knowledge between the school and the community, where it is possible to reach the student's sensitivity, and impact their identity construction process. But if in practice it is possible to strengthen the pedagogical sense of the SSSP, if the operational impediments are overcome, if it is possible to expand as a transversal vision present from an early age in the educational process, if it has institutional support and a strong legal basis, youth will also be allowed to have a better formative setting. Ultimately, it is not expected that the SSSP only manages to link the knowledge of the school with the knowledge of the context, but that their real learning scenarios also turn students into social, political, and cultural actors with a transforming role in the face of a system of inequality.

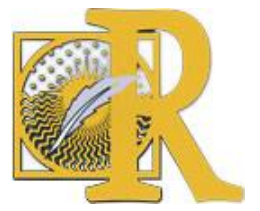

Fecha de recepción: 20-06-2020 Fecha de aceptación: 24-06-2020

Ortega-Torres, W., Vahos, A. \& Sánchez Medina, J. A. (2020). Escuela y comunidad. La experiencia colombiana con los Proyectos de Servicio Social Estudiantil 
Those students in training are given competencies to discern, question, evaluate, and confront themselves and their environment. If young people see the possibilities that real and authentic learning offers them for their development, if they incorporate these new tools into their identity construction if they become aware of their environment, if they empower themselves with critical and militant discourses about their reality and about themselves, a real change can be started towards social actors who will become leaders of transformation and multipliers of change in a country whose most powerful engine can be education.

\section{References.}

- Abajo, J. E. \& Carrasco, S. (Eds.). (2004). Experiencias y trayectorias de éxito escolar de gitanas y gitanos en España. Encrucijadas sobre educación, género y cambio cultural. CIDE / Instituto de la Mujer.

- Abreu, G., Bishop, A.J. \& Pompeu, G. (1997). What children and teachers count as mathematics? En Learning and teaching mathematics (pp. 233-364). Psychology Press.

- Campo Tejedor, A. (2003). Investigar y deconstruir el estigma en barrios marginales. Un estudio de caso. Zainak, Cuadernos de Antropología-Etnográfica, 24, 803 - 817.

- Decree 1860. Official Journal No 41.473 Ministry of National Education of Colombia, 5 August 1994.

- Díez Palomar, J., \& Flecha García, J. (2010). Comunidades de aprendizaje: un proyecto de transformación social y educativa. Revista interuniversitaria de formación del profesorado, 67, 19-30.

- Engestrom, Y. (1991). Non Scholae sed Vitae Discimus: Toward Overcoming the Encapsulation of School Learning. Learning and Instruction, 1(3), 243-259.

- Flecha, A., García, R., Gómez, A., \& Latorre, A. (2009). Participación en escuelas de éxito: una investigación comunicativa del proyecto Includ-ed. Cultura y Educación, 21(2), 183196.

- Goffman, E. (2006). Estigma: la identidad deteriorada (1rst ed. in Spanish). Amorrortu.

- Jeynes, W. (2007). The Relationship Between Parental Involvement and Urban Secondary School Student Academic Achievement: A Meta-Analysis. Urban Education, 42(1), 82-110.

- Lave, J., \& Wenger, E. (1991). Situated learning: legitimate peripheral participation. Cambridge University Press.

- Law 115. Congress of the Republic of Colombia, 8 February 1994.

- Meijers, F. (2002). Career Learning in a Changing World: The Role of Emotions. International Journal for the Advancement of Counselling, 24(3), 149-167.

- MEN (s.f.a). Currículo [Publicación]. Recuperado de: https://www.mineducacion.gov.co/1621/article-79413.html

- MEN (s.f.b). Proyecto Educativo Institucional - PEI [Publicación]. Recuperado de: https://www.mineducacion.gov.co/1621/article-79361.html

- MEN (s.f.c). Planes de Mejoramiento [Publicación]. Recuperado de: https://www.mineducacion.gov.co/1621/article-80089.html

- Messiou, K. (2012). Confronting marginalization in education a framework for promoting inclusion. Routledge.

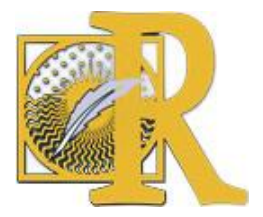

Fecha de recepción: 20-06-2020 Fecha de aceptación: 24-06-2020

Ortega-Torres, W., Vahos, A. \& Sánchez Medina, J. A. (2020). Escuela y comunidad. La experiencia colombiana con los Proyectos de Servicio Social Estudiantil

International Journal of Educational Research and Innovation (IJERI), 14, 304-323 ISSN: 2386-4303 DOI https://doi.org/10.46661/ijeri.4986 
- Moliner, M. O. (2008). Condiciones, procesos y circunstancias que permiten avanzar hacia la inclusión educativa: retomando las aportaciones de la experiencia canadiense. REICE: Revista Electrónica Iberoamericana sobre Calidad, Eficacia y Cambio en Educación, 6(2), 27-44.

- Nunes, T. (1999). Mathematics learning as socialization of the mind. Mind, Culture and Activity, 6(1), 33 - 52.

- Pulg Rovira, J., Gijón, M., Martín, X., \& Rubio, L. (2011). Aprendizaje-servicio y Educación para la Ciudadanía. Revista de educación, 1, 45-67.

- Resnick, L. (1987). The 1987 Presidential Address Learning In School and Out. Educational Researcher, 16(9), 13-54.

- Resolution 4210. Ministry of National Education of Colombia12 September 1996.

- Rogoff, B. (1993) Aprendices del pensamiento. El desarrollo cognitivo en el contexto social. Ediciones Paidós.

- Rogoff, B., Mistry, J., Göncü, A., Mosier, C., \& Rogoff, B. (1993). Guided participation in cultural activity by toddlers and caregivers. Monographs of the Society for Research in Child Development, 58(8), v-vi.

- Rogoff, B. (1997). Los tres planos de la actividad sociocultural: apropiación participativa, participación guiada y aprendizaje. In J. V. Werstch, P. del Río \& A. Alvarez (Eds.) La mente socio-cultural. Aproximaciones teóricas y aplicadas. Fundación Infancia y Aprendizaje.

- Rogoff, B. (2003). The Cultural Nature of Human Development. Oxford University Press.

- Sánchez Upegui, A. (2010). Introducción: ¿qué es caracterizar? Fundación Universitaria Católica del Norte.

- Santana, L. E., Feliciano, L. \& Jiménez, A. B. (2016). Apoyo familiar percibido y proyecto de vida del alumnado inmigrante de Educación Secundaria. Revista de Educación, 372, 35-62.

- Scribner, S. (1997). Studying literacy at work: bringing the laboratory to the field. In Scribner, S., \& Tobach, E. (Eds.), Mind and social practice. Selected Writings of Sylvia Scribner (pp. 223-229). Cambridge University Press.

- Vygotski, L., Cole, M., \& Luria, A. (1989). El desarrollo de los procesos psicológicos superiores. Crítica.

- Wenger, E. (2001). Comunidades de prácticas. Aprendizaje, significado e identidad. Editorial Paidós.

\footnotetext{
1 "My Community is my School" program

${ }^{2}$ According to the Colombian Ministry of National Education, the levels of formal education are preschool education, which will comprise a minimum of a compulsory degree; basic education, with a duration of nine grades that will be developed in two cycles: primary with five grades (1st, 2nd, 3rd, 4th, and 5th) and secondary with four grades (6th, 7 th, 8 th ${ }^{\circ}$, and $9^{\circ}$ ); and secondary education, with two grades (10th and 11th), to culminate with the bachelor's degree.
}

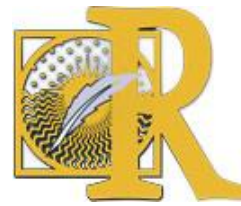

Fecha de recepción: 20-06-2020 Fecha de aceptación: 24-06-2020

Ortega-Torres, W., Vahos, A. \& Sánchez Medina, J. A. (2020). Escuela y comunidad. La experiencia colombiana con los Proyectos de Servicio Social Estudiantil

International Journal of Educational Research and Innovation (IJERI), 14, 304-323 ISSN: 2386-4303 DOI https://doi.org/10.46661/ijeri.4986 
${ }^{3}$ The Municipal Education Secretariat of Cali registers a total of 91 official institutions, that is, 91 main educational centers that concentrate the administrative area; at the same time that these main offices are made up of 326 satellite offices, which are independent physical plants but which together form a single institution. For example, the Carlos Holguín Mallarino institution has a main office under the same name and has two satellite offices, Niño Jesús de Atocha and Miguel de Pombo. The three headquarters, one main and two satellites make up the Carlos Holguín Mallarino institution.

${ }^{4}$ From an investigative perspective, the characterization refers to the initial phase of qualitative identification of the state of the SSSP, investigating, among other aspects, the components, actors, processes and contexts of the experience (Sánchez Upegui, 2010).

${ }^{5}$ According to the Ministry of National Education, MEN for its initials in Spanish (s.f.a), the curriculum is the set of criteria, study plans, programs, methodologies, and processes that contribute to comprehensive training and the construction of national, regional, and local cultural identity, including human resources, academics and physicists to implement the policies and carry out the institutional educational project.

${ }^{6}$ According to the MEN (s.f.b), the Institutional educational project is the navigation chart of the schools, where the principles and purposes of the establishment, available and necessary teaching and teaching resources, the pedagogical strategy, the regulations for teachers and students and the management system.

${ }^{7}$ According to the MEN (s.f.c), the Institutional Improvement Plan is the set of goals, actions, procedures and adjustments that the institution defines and implements in certain periods of time so that the aspects of educational management are integrated around commonly agreed purposes and support the fulfillment of your academic mission.

${ }^{8}$ In Colombia, higher education refers to the training process to which one aspires once formal education is completed. To access the university programs, you must accredit the bachelor's degree and have the results of the "Saber Tests" or State Exam, which is the compulsory official test that is presented when you graduate from high school.

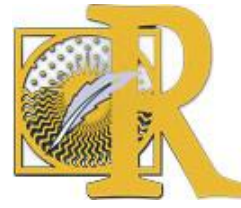

Fecha de recepción: 20-06-2020 Fecha de aceptación: 24-06-2020

Ortega-Torres, W., Vahos, A. \& Sánchez Medina, J. A. (2020). Escuela y comunidad. La experiencia colombiana con los Proyectos de Servicio Social Estudiantil

International Journal of Educational Research and Innovation (IJERI), 14, 304-323

ISSN: 2386-4303 DOI https://doi.org/10.46661/ijeri.4986 